\title{
Miejsca schronienia w górach. Działalność budowlana towarzystw górskich i idealizacja Karpat w czasach nowoczesnych
}

\author{
https://doi.org/10.19195/2084-4107.13.20
}

Fizyczna forma krajobrazów jest nierozerwalnie związana $\mathrm{z}$ ich przedstawieniem i interpretacją ${ }^{1}$. Krajobrazy górskie nie są w tym względzie wyjątkiem. $\mathrm{W}$ czasach nowoczesnych ich postrzeganie i forma istotnie się zmienily, a w miejsce lęku pojawiła się fascynacja. Góry oferowały wspinającym się i podróżującym powierzchnie projekcyjne dla ich własnych doświadczeń i zabarwień kulturowych $^{2}$. Ta obrazowa strona krajobrazu jest rezultatem świadomego procesu, w którym społeczne nierówności uładzono w środowisku naturalnym ${ }^{3}$. Krajobraz pełni funkcję środka tworzącego porządek społeczny ${ }^{4}$, idealizacja gór zaś odbywała się nie tylko w pisanych i obrazowych przedstawieniach na płaszczyźnie interpretacji, lecz także komplementarnie przez aktywne wykorzystanie oraz świadome kształtowanie przestrzeni górskiej. Na takim tle niniejszy artykuł pokazuje działalność budowlaną towarzystw górskich Karpat w czasach nowoczesnych z perspektywy społeczno-historycznej, przez co — biorąc pod uwagę różnice społeczno-ekonomiczne dzielące zaangażowane $\mathrm{w}$ ten proces postaci - wychodzi poza przeważającą w badaniach interpretację nawiązującą do uwarunkowań narodowych.

W centrum tekstu stoją schroniska, które oferowały ludziom czasowe schronienie lub możliwość zatrzymania się na odpoczynek w trudno dostępnym i niezagospodarowanym w inny sposób terenie. Miejsca takie, nazywane Schutzhaus, Berghütte czy Bergbaude tudzież horská chata, útulña, menedékház lub schronisko, różniły się od wiejskich domów weekendowych i noclegowni, które nabrały znaczenia $\mathrm{w}$ XX wieku ${ }^{5}$. Schroniska stawiane były na początku przez właścicieli ziemskich, przez przedsiębiorcze osoby prywatne działające $\mathrm{w}$ gastronomii i turystyce, a także przez instytucje państwowe związane z leśnictwem lub ochroną

${ }^{1}$ Definicja krajobrazu oraz związek pomiędzy jego fizyczną rzeczywistością a reprezentacją wydobytą przez człowieka są kwestią intensywnie dyskutowaną w geografii. Dobry ogląd zob. K.M. Morin, Landscape: Representing and interpreting the world, [w:] Key Concepts in Geography, red. N.J. Clifford et al., Los Angeles 2009, s. 286-299.

2 Tak na przykład brytyjski pisarz Robert MacFarlane w swej zabarwionej autobiograficznie historii wspinaczki - idem, Montains of the Mind, New York 2003.

${ }^{3}$ Zob. D. Cosgrove, Modernity, community and the landscape idea, ,Journal of Material Culture" 11, 2006, nr 1-2, s. 49-66, tu: s. 51.

4 Zob. W.T. Mitchell, Landscape and Power, Chicago 2002.

5 Oprócz publikacji wydawanych przez same towarzystwa górskie prace z zakresu nauk społecznych i o architekturze oferują przegląd zagadnienia. Zob. P. Grupp, Faszination Berg: Die Geschichte des Alpinismus, Köln-Weimar-Wien 2003, s. 172-181; M. Kulig, Architektura tatrzańskich schronisk górskich Polskiego Towarzystwa Tatrzańskiego w dwudziestoleciu międzywojennym, Warszawa 2003; G. Kerschbaumer, Hochalpine Architektur, Wien 2017. Porównanie z weekendowymi chatami zob. J. Schüler, Weekendove chaty, Praha 1937. 
granic. Wraz z nadejściem turystyki w drugiej połowie XIX wieku od Europy poprzez Amerykę Północną aż po Australię działalnością budowlaną zajęły się powstające towarzystwa górskie, które są już przedmiotem licznych prac historycznych, poświęconych zazwyczaj poszczególnym towarzystwom lub regionom ${ }^{6}$. W odróżnieniu od nich niniejszy artykuł jest pracą syntetyczną, posługującą się przykładami z całego obszaru Karpat, i analizującą, opierając się na budowie i wykorzystaniu schronisk, zawłaszczanie przestrzeni górskiej oraz związaną z nim interakcję z miejscową ludnością jako proces idealizacji. Podstawę do tego stanowią relacje z podróży, przewodniki górskie oraz pisma towarzystw górskich, które ukazywały się w okresie od założenia pierwszych towarzystw karpackich w latach siedemdziesiątych XIX wieku aż do początku I wojny światowej. Należą do nich takie roczniki, jak niemiecko- i węgierskojęzyczny „Jahrbuch des Ungarischen Karpathen-Vereines/Magyarországi Kárpátegylet évkönyve" "7 niemieckojęzyczny „Jahrbuch des Siebenbürgischen Karpathen-Vereins” i polskojęzyczny „Pamiętnik Towarzystwa Tatrzańskiego" ". Jakkolwiek te tworzone przez podróżnych źródła opisują przestrzeń górską z zewnętrznej perspektywy, to zawierają też opisy różnorodnych spotkań z ludnością górską, a także z ludźmi przebywającymi tam ze względu na wykonywany zawód, jak myśliwi lub żandarmi. Artykuł opisuje w dwóch częściach spotkania na uważanym za pusty terenie górskim. Pierwsza część zajmuje się rolą, jaką odgrywało schronisko górskie w turystycznym udostępnianiu Karpat. Druga naświetla zawłaszczanie przestrzeni przez towarzystwa górskie oraz związaną z nim idealizację gór.

\section{Schronisko przesuwa granice tego, co znane}

Karpaty są pasmem górskim o długości ponad 1500 kilometrów, które w badanym okresie leżały w dużej części w Austro-Węgrzech i graniczących z nimi terenach. Łańcuch górski rozciąga się wraz ze swymi odnogami od Beskidów (Beskydy) na wschodnich Morawach poprzez Tatry, podówczas na granicy galicyjsko-węgierskiej, aż po Siedmiogród i Banat na południu wraz z ówczesnym pograniczem węgiersko-rumuńskim. Zainteresowanie Karpatami w czasie ich

6 J. Polášková, J. Polášek, Historie Beskydské turistiky. Sto dvacet let organizované turistiky v Moravskoslezských Beskydách. Turistické chaty na Frýdecko-Misteku, Třinecku a Jablunovsku, Ostrava 2009; Z dziejów Towarzystwa Tatrzańskiego i Polskiego Towarzystwa Tatrzańskiego (1873-1950), red. A. Kurek, W.A. Wójcik, Kraków 2016; M. Wedekind, Der Siebenbürgische Karpatenverein (1880-1944). Ein Beitrag zur Sozialgeschichte Siebenbürgens, „Halbjahresschrift für südosteuropäische Geschichte, Literatur und Politik" 16, 2004, nr 2, s. 71-86.

${ }^{7}$ Rocznik ten wydawany był w latach 1874-1883 dwujęzycznie: po niemiecku i węgiersku, a od 1884 roku jako dwa osobne wydania językowe.

8 Ze względu na wielojęzyczny charakter regionu Karpat w niniejszym artykule przy pierwszej wzmiance o miejscu zostają wymienione jego nazwy we wszystkich językach, a następnie posługujemy się tylko wersją polską. W odniesieniu do nazw towarzystw, schronisk, jezior i dolin ograniczamy się do polskiej wraz z odpowiednikami innojęzycznymi w nawiasach. 
poznawania od XVIII wieku kierowało się, w odróżnieniu od zainteresowania Alpami, nie tyle na połączenie osi komunikacyjnych, ile było istotne ze względu na geopolityczne położenie tegoż pasma gór ${ }^{9}$. Przekraczanie granicy odgrywało też ważną rolę w relacjach z podróży, jako że podróżni coraz to napotykali żandarmów tudzież celników, którzy czasami oferowali im nocleg. Jednocześnie przebieg granic stanowił ograniczenie swobody ruchu turystycznego. Spotykało się to również z krytyką. Mianowicie jeden $\mathrm{z}$ wędrujących po pograniczu węgiersko-rumuńskim życzył sobie, aby w górach zamiast paszportu mógł okazywać legitymację członkowską swego towarzystwa górskiego ${ }^{10}$. To, że także organizacje turystyczne nie były wolne od kontrowersji związanych z przebiegiem granic państwowych, ukazuje długoletni spór prawny o przynależność państwową jeziora Morskie Oko w Tatrach Wysokich na granicy między Krajem Koronnym Galicji/Galizien/Halycyna w Austrii a Komitatem Spiskim/Zips/Szepes/Spiš na Węgrzech. Spór ten, w którym udzielały się również działające na tym terenie towarzystwa górskie i ich członkowie, został rozstrzygnięty dopiero w 1902 roku — na korzyść Galicji ${ }^{11}$.

Na tle takich konfliktów olbrzymia część literatury badawczej dotyczącej udostępniania i zawłaszczania przestrzeni górskiej zajmuje się narodowymi interpretacjami krajobrazu. W ten sposób symbolika gór została przejęta od Alp poprzez Bałkany po Karpaty przez projekty narodowe, a łańcuchy górskie do dziś zajmują poczesne miejsce $\mathrm{w}$ świadomości związanej z różnorodnymi tożsamościami w państwach narodowych ${ }^{12}$. W szczególności z punktu widzenia polskiego ruchu narodowego w późnym XIX wieku Karpaty, a przede wszystkim Tatry, zajęły główną rolę w konstrukcji krajobrazu narodowego ${ }^{13}$. Obok krajobrazu była to dotąd w niewielkim stopniu znana lokalna ludność górska, a mianowicie górale, których intelektualiści uznali za ucieleśnienie polskich chłopów ${ }^{14}$. Takie zajęcie prowadziło do konfliktów

9 Zob. T. Matuska, Die Erforschung und alpinistische Erschließung der Karpaten, „Das achtzehnte Jahrhundert und Österreich: Jahrbuch der Österreichischen Gesellschaft zur Erforschung des Achtzehnten Jahrhunderts” 26, 2012, s. 255-265, tu: s. 258-259; „Die Erschließung der Karpaten” 2015, nr 8. Danubiana Carpathica, red. H. Heppner.

${ }^{10}$ E. Barcza, In den Siebenbürgischen Karpaten, „Jahrbuch des Ungarischen Karpathenvereins” 31, 1904, s. 75-94, tu: s. 76.

11 Der Streit um das Meerauge, „Österreichische Zeitschrift für Vermessungswesen” 7, 1909, nr 9, s. 279-281.

${ }^{12}$ L. Lipták, Die Tatra im slowakischen Bewusstsein, [w:] Heroen, Mythen, Identitäten. Die Slowakei und Österreich im Vergleich, red. H. Stekl, E. Mannová, Wien 2003, s. 261-288; U. Brunnbauer, R. Pichler, Mountains as "lieux de mémoire". Highland values and nation-building in the Balkans, „Balkanologie" 6, 2002, nr 1-2, s. 77-100; O. Zimmer, In search of natural identity: Alpine landscape and the reconstruction of the Swiss nation, „Comparative Studies in Society and History” 40, 1998, nr 4, s. 637-665.

13 Zob. P. Dabrowski, "Discovering” the Galician borderlands: The case of the Eastern Carpathians, „Slavic Review” 64, 2005, nr 2, s. 380-402; B. Hoenig, Kleinod und Ressource: Die Polnische Naturschutzbewegung und die Tatra, „Bohemia” 54, 2014, nr 1, s. 56-73.

14 D. Crowley, Finding Poland in the margins: The case of the Zakopane style, ,Journal of Design History" 14, 2001, 2, s. 105-116, tu: s. 108. 
związanych z roszczeniami różnych stron w regionie, ciągnącymi się przez dziesiątki lat ${ }^{15}$. Do konfliktów mogło dochodzić w ramach jednej wspólnoty narodowej pomiędzy centrum a regionem, jak to ukazuje Martin Pelc na przykładzie relacji między Towarzystwem Górskim Radogoszcz (Pohorská jednota Radhošt') a Klubem Czeskich Turystów (Klub českých turistů) z siedzibą w Pradze ${ }^{16}$. Mogły one jednak kształtować się na podstawie przynależności narodowych, jak argumentuje w innym przyczynku dotyczącym Karkonoszy na granicy czesko-śląskiej. Opisuje mianowicie powstające tam we wczesnym XX wieku schroniska i wieże widokowe jako „bastiony narodowe” wspólnot interesów czeskich i niemieckich. Krajobraz górski został „całkowicie posegregowany i poddany konsekwentnej etnicyzacji”, porozumienie zaś pomiędzy stronami stanowiło wyjątek ${ }^{17}$. W przeciwieństwie do tego Pieter Judson zaznacza, w odniesieniu do innych regionów Austro-Węgier, że przewodniki tudzież miejsca noclegów o narodowym nastawieniu kierowane do niemieckich podróżnych odgrywały „,bardzo niewielką rolę"18.

Czy to z pobudek narodowych, czy innych zawłaszczanie przestrzeni jako powierzchni reprezentacyjnej dla własnych interesów stanowiło istotną motywację do wznoszenia schronisk w czasach współczesnych. Z początku góry były opisywane przez podróżnych jako niezamieszkana i niegościnna przestrzeń wywołująca lęk ${ }^{19}$. Karpaty stanowiły dla wielu podróżnych z metropolii Austro-Węgier oraz z zachodniej Europy w XIX i wczesnym XX wieku terra incognita, jak wynika z licznych źródeł ${ }^{20}$. Położone na zachód od Karpat Alpy były podróżnikom górskim często lepiej znane. Dla Patrice Dabrowski Karpaty to pewne europejskie frontier, oferujące na obrzeżu pewnego obszaru możliwość zetknięcia się z nieznanym $^{21}$. Z takiego samego ekspansjonistycznego punktu widzenia wychodzi Marie Louise Pratt w swej koncepcji contact zone, w której spotykają się takie

15 B. Hoenig, Geteilte Berge. Eine Konfliktgeschichte der Naturnutzung in der Tatra, Göttingen 2018.

${ }^{16}$ M. Pelc, Pohorská jednota „Radhošt” a Klub českých turistů: problém vztahu regionu, „Acta Historica Universitatis Silesianae Opaviensis. Confinia Silesiae” 2008, nr 1, s. 425-437.

${ }_{17}$ M. Pelc, Orte der Selbstpositionierung. Deutsche und tschechische Wandervereine vor 1945, [w:] Zwischen Exotik und Vertrautem. Zum Tourismus in der Habsburgermonarchie und ihren Nachfolgestaaten, red. P. Stachel, M. Thomsen, Bielefeld 2014, s. 233-242, tu: s. 236, 241.

18 P.M. Judson, Reisebeschreibungen in der „Südmark“ und die Idee der deutschen Diaspora nach 1918, [w:] Zwischen Exotik und Vertrautem..., s. 59-76, tu: s. 63.

19 T. Posewitz, Die Geschichte des Ungarischen Karpathen-Vereines seit seinem Bestande, „Jahrbuch des Ungarischen Karpathen-Vereines” 21, 1894, s. 1-211, tu: s. 14. O roli przestrzeni górskiej „,poza zamieszkałym światem” zob. też M. Scharfe, Berg-Sucht: eine Kulturgeschichte des frühen Alpinismus 1750-1850, Wien-Köln-Weimar 2007, s. 196-203.

${ }^{20}$ M. Rey, Zagajenie pierwszego walnego zgromadzenia Towarzystwa Tatrzańskiego, „Pamiętnik Towarzystwa Tatrzańskiego" 1, 1876, s. 7-8, tu: s. 7; A.F. Heksch, Illustrirter Führer durch Pressburg und seine Umgebungen, das Waagthal und die kleinen Karpathen, Wien-Pressburg 1885, s. vi; Die Karpaten. Balthasar Hacquet und das „vergessene“ Gebirge in Europa, red. K. Scharr, Innsbruck 2004.

${ }^{21}$ P. Dabrowski, Constructing a Polish landscape: The example of the Carpathian frontier, „Austrian History Yearbook” 39, 2008, s. 45-65, tu: s. 46. 
osoby, jak miejski intelektualista i górski pasterz, które przedtem były od siebie oddzielone przestrzennie i historycznie. Pratt nie kieruje uwagi na różnice między podróżnym a miejscowym, lecz podkreśla $\mathrm{w}$ relacjach z podróży ich interakcję, rozgrywającą się często w bardzo niesymetrycznym stosunku władzy ${ }^{22}$.

Tak jak Alpy Karpaty nie zostały w XIX wieku udostępnione turystyce z inicjatywy ludności lokalnej, lecz z inicjatywy alpinistów i alpinistek z miast Austro-Węgier lub z innych krajów. Byli oni częścią połączonej w sieć elity, która w tamtym czasie uczyniła sobie z gór ,plac zabaw dla Europy”, tak jak w osławionej metaforze brytyjskiego alpinisty Lesliego Stephena ${ }^{23}$. Pojedyncze wsie, jak Zakopane, stały się przy tym miejscem spotkań miejskich intelektualistów i urosły w ciągu niewielu dziesięcioleci do rangi turystycznego centrum podzielonej Polski ${ }^{24}$. Ci górscy podróżnicy z miast wciąż byli jednak zdani na wsparcie ze strony ludności miejscowej, która mogła ich prowadzić po nieznanych górach. W źródłach często brakuje nazwisk tych ludzi i dlatego zazwyczaj stoją oni na dalszym planie analiz. Dwie publikacje z dziedziny historii kolonialnej, które niedawno się ukazały, zajęły się towarzyszącymi wspierającymi podróżników w czasie europejskich podróży odkrywczych, ukazując wielki potencjał takiej perspektywy badawczej. Postaci te dzięki swojej wiedzy, kontaktom oraz sile mięśni umożliwiały przeprowadzenie podróży ${ }^{25}$.

Wyobrażenie o tym, jak górskim podróżnikom prezentowały się Karpaty w połowie XIX wieku, kiedy były niemal całkowicie pozbawione infrastruktury turystycznej, daje litografia Carla Kořistka (zob. ilustracja 1) z 1864 roku. Kořistka był profesorem w Krajowym Instytucie Politechnicznym w Pradze, a swoją relację z podróży opublikował w wydawnictwie w Rzeszy Niemieckiej. Jego rysunek ukazuje jezioro Morskie $\mathrm{Oko}^{26} \mathrm{w}$ Dolinie Rybiego Potoku, które już na początku XIX wieku odznaczało się wielką siłą przyciągania turystów, jak pokazują księgi gości z położonych niedaleko wsi ${ }^{27}$. Kořistka lamentował, że jeśli chodzi o możliwości noclegowe, to w Karpatach „właściwie w ogóle nie jest o to zadbane"28.

22 M.L. Pratt, Imperial Eyes. Travel Writing and Transculturation, London-New York 1992, s. 6-7.

${ }^{23}$ L. Stephen, The Playground of Europe, London 1871.

24 S. Keym, Kulturhauptstadt des geteilten Polen? Zum Beitrag der Musik zur Stilisierung Zakopanes und der Tatra-Region zu einem nationalen Wertezentrum, [w:] Im Herzen Europas. Nationale Identitäten und Erinnerungskulturen, red. D. Altenburg, L. Ehrlich, J. John, Köln-Weimar-Wien 2008, s. 307-325.

${ }^{25}$ Der Träger. Zu einer „tragenden” Figur der Kolonialgeschichte, red. S. Malzner, A.D. Peiter, Bielefeld 2018; M. Volker, Im Schatten der Entdecker. Indigene Begleiter europäischer Forschungsreisender, Berlin 2018.

${ }^{26}$ Po niemiecku określane podówczas jako „Fischsee” i tak też w podpisie do litografii Koristka.

27 S. Weber, Franz Klein, das Koscielisker Thal und der Grosse Fisch-See, „Jahrbuch des Ungarischen Karpathen-Vereines" 24, 1897, s. 34-45, tu: s. 39.

28 C. Kořistka, Die Hohe Tatra in den Central-Karpaten. Eine geographische Skizze verfasst auf Grundlage einer Bereisung. Ergänzungsheft No. 12 zu Petermann's „,Geographischen Mittheilungen“, Gotha 1864. 
Najczęściej podróżny musiał być szczęśliwy, jeśli udało mu się dostać na noc brudne łóżko w izdebce gościńca, co praski profesor uważał w sumie za zbyt drogie. Jak pisał, lepszy nocleg można znaleźć tylko w kurortach, które jednak leżą zbyt daleko, aby przedsiębrać z nich wycieczki w góry. Tak jak w wypadku wędrówki Kořistki tak i przy innych podróżach w relacjach pojawia się ciągle kwestia braku możliwości noclegowych, a podróżni poruszają się od miasta do miasta, ograniczając wycieczki w góry do wielogodzinnych wędrówek. Dopiero w późniejszych relacjach, wraz z rozbudową infrastruktury i wznoszeniem schronisk, pojawiają się wielodniowe wycieczki górskie połączone z noclegiem.

Pierwsze chaty w górach były budowane dla ludzi żyjących i pracujących w Karpatach, aby zapewnić im miejsce noclegu w czasie wypasu lub transportu towarów. W powstających obok gospodach nocowali głównie robotnicy leśni, strażnicy graniczni i żołnierze. Ówczesne chaty górskie nie były zbyt komfortowo urządzone i często łączyły pomieszczenie mieszkalne z oborą. Dach chroniący przed deszczem, śniegiem i burzą oraz palenisko, przy którym można się było ogrzać lub coś ugotować, wystarczały. Takie szałasy pasterskie występują w relacjach z podróży najczęściej wtedy, gdy podróżni zabłądzili lub gdy zaskoczyła ich zła pogoda. Dopóki w pewnych rejonach nie było hoteli ani gospód, dopóty podróżni byli zdani w swych długich wędrówkach na gościnność chłopów oraz pasterzy i nawet się na to przygotowywali, zabierając z sobą jako wyraz wdzięczności alkohol, tytoń lub inne towary ${ }^{29}$. Na fotografii z 1909 roku, wykonanej przez wiedenkę Emmę Lovy, widać taką prostą chatę (zob. ilustracja 2) znajdującą się w dolinie poniżej Piatra Rea w Górach Rodniańskich, która była zamieszkana przez żydowskiego pasterza. Z relacji Lovy wynika, że aktywnie dążyła do spotkania z mężczyzną. Pisze też, że ceniła możliwości poznania lepiej „etnograficznych i gospodarczych stosunków" kraju ${ }^{30}$.

Wraz ze wzrostem liczby podróżujących w przestrzeni górskiej po prosto urządzonych chatach nastąpiły takie, których standard był wyższy. Te czyniły góry bardziej przystępnymi „dla ceniącego komfort i wygodę przyjaciela natury”, jak zostało trafnie sformułowane w relacji z 1898 roku $^{31}$. Jedno z pierwszych schronisk, z których korzystali podróżni w czasie swoich aktywności w wolnym czasie, było to przedstawione na litografii Kořistki na brzegu Morskiego Oka. Schronisko to było wymieniane po raz pierwszy już we wczesnym XIX wieku, a zbudowane zostało na zlecenie ówczesnego właściciela tych ziem. We wspomnieniach malarza podróżującego po Tatrach Walerego Eljasza Radzikowskiego z 1903 roku znajduje się opis wyposażenia tegoż schroniska, które było w opłakanym stanie. Brakowało mu dachu, w środku pomieszczenia płonął ogień, a drzwi i okiennice

${ }^{29}$ K. Kalchbrenner, Ein Ausflug in das Kupferschächtenthal, „Jahrbuch des Ungarischen Karpathen-Vereines" 2, 1875, s. 219-245, tu: s. 237.

${ }^{30}$ E. Lövy, Ein Ausflug in die Rodnaer Alpen, „Jahrbuch des Ungarischen Karpathen-Vereines" 37, 1910, s. 16-40, tu: s. 17.

${ }^{31}$ L., Das „Friedrich“-Schutzhaus, „Jahrbuch des Ungarischen Karpathen-Vereines” 25, 1898, s. 156-168, tu: s. 156. 
już spłonęły, użyte przez podróżnych jako materiał opałowy. Jako że w Tatry przybywało coraz więcej podróżnych, Eljasz Radzikowski odczuwał brak stosownego schronienia jako hańbę części Polski znajdującej się pod panowaniem austriackim („wstyd dzielnicy Polski pozostającej pod rządem austriackim”), którą można zmazać, tylko tworząc towarzystwa górskie ${ }^{32}$. Dziś jeszcze stoi tam Schronisko nad Morskim Okiem, wzniesione w 1908 roku przez Towarzystwo Tatrzańskie po pożarach wcześniejszych placówek.

\section{Towarzystwa górskie, podróżni i ludność zamieszkująca góry w strefie kontaktu}

Towarzystwo Tatrzańskie było tylko jednym z towarzystw górskich założonych w Karpatach w drugiej połowie XIX wieku. Po ugodzie austro-węgierskiej z 1867 roku liczba towarzystw w obu częściach Rzeszy gwałtownie wzrosła ${ }^{33}$. Towarzystwa górskie należały do wspólnot, które poświeciły się badaniu i kształtowaniu otaczającego krajobrazu. W wielu miejscowościach i regionach Austro-Węgier tworzyły się stowarzyszenia dla wiedzy o kraju, towarzystwa upiększania, towarzystwa turystyczne i wędrowne oraz stowarzyszenia dla wspierania ruchu turystycznego. Wszystkie koordynowały rozliczne nowe działania podejmowane w czasie wolnym w krajobrazie górskim. Podczas gdy pielgrzymki do wysoko położonych kościołów i kapliczek miały dłuższą tradycję, wędrówka, wspinaczka i jazda na nartach przedstawiały nowe czynności, które u niektórych współczesnych budziły podziw graniczący z niezrozumieniem lub rozbawieniem wywoływanymi przez trudy tych bogatych hobby ${ }^{34}$.

Po założeniu Szwajcarskiego Alpen-Club (1863) oraz Niemieckiego i Austriackiego Związku Alpejskiego (1862/1869) $)^{35}$ powstały również pierwsze inicjatywy założenia podobnego związku w Karpatach. Przodowali tu medycy, członkowie armii, botanicy oraz artyści. Zawołanie do stworzenia jednego towarzystwa karpackiego obejmującego cały łańcuch górski nie przyniosło rezultatów ${ }^{36}$, a krótko

32 W.E. Radzikowski, Wspomnienie o schroniskach nad Morskim Okiem, „Pamiętnik Towarzystwa Tatrzańskiego" 24, 1903, s. 120-132, tu: s. 123.

33 W Austrii zakładanie towarzystw umożliwiło prawo o zgromadzeniach i stowarzyszeniach z 1867 roku. Na Węgrzech prawo do stowarzyszania się do końca monarchii habsburskiej nie zostało prawnie uregulowane, stosowanie zaś następowało poprzez rozporządzenie Ministerstwa Spraw Wewnętrznych. Zob. też A. Toth, Die Genehmigungspraxis politischer Vereine und Parteien in Ungarn 1892-1896, „Ungarn Jahrbuch” 18, 1990, s. 75-105, tu: s. 77.

${ }^{34}$ E. Lüdecke, Ein Ausflug zum Bullea See (29. Juni bis 1. Juli 1883), „Jahrbuch des Siebenbürgischen Karpathen-Vereins" 4, 1884, s. 96-108, tu: s. 103.

35 W 1873 roku połączonego w Niemiecki i Austriacki Związek Górski.

${ }^{36}$ Zgodnie z prezentacją lekarza wojskowego Theodora Posewitza (1894) z okazji jubileuszu pierwszą inicjatywę utworzenia Towarzystwa Karpackiego podjął Heinrich Wallmann z Salzburga, który jako c.k. lekarz pułku stacjonował w latach sześćdziesiątych XIX wieku najpierw w Koszycach/Kaschau/Košice/Kassa, a następnie we Lwowie/Lemberg/L'viv. Po wędrówce w Tatry Wysokie 
potem (w 1873 roku) powstały pierwsze regionalne towarzystwa karpackie: Węgierskie Towarzystwo Karpackie//Magyarországi Kárpátegylet z siedzibą w Starym Smokowcu/Altschmecks/Tátrafüred/Starý Smokovec ${ }^{37}$, Galicyjskie Towarzystwo Turystyczne, względnie Towarzystwo Tatrzańskie w Krakowie, oraz Siedmiogrodzkie Towarzystwo Alpejskie w Braszowie/Kronstadt/Braşov/Brassó ${ }^{38}$. Oprócz tego w kolejnych dziesięcioleciach powstawały kolejne mniejsze towarzystwa regionalne ${ }^{39}$. Towarzystwa karpackie, tak jak związki alpejskie, były podzielone na sekcje regionalne, które poświęcały się określonym częściom regionu górskiego. Ze względu na dużą liczbę niemieckojęzycznych członków Węgierskiego Towarzystwa Karpackiego i Siedmiogrodzkiego Towarzystwa Karpackiego kontakty ze związkami alpejskimi w Austrii i Rzeszy Niemieckiej były intensywne. W przeciwieństwie do Towarzystwa Tatrzańskiego słowiańskojęzyczna ludność była w mniejszości w towarzystwach węgierskich ${ }^{40}$. Poprzez członkostwa honorowe oraz wymianę pism od początku istniała współpraca pomiędzy towarzystwami karpackimi, także poza granicą węgiersko-galicyjską ${ }^{41}$.

Towarzystwa karpackie postawiły sobie za zadanie zbadanie i udostępnienie przestrzeni górskiej. W tym celu rozpowszechniały informacje dla podróżnych i starały się popularyzować swoje regiony w celach turystycznych, wydając własne pismo związkowe, otwierając $\mathrm{w}$ pobliskich miejscowościach muzea górskie, wspierając lokalny przemysł, a także publikując zdjęcia fotograficzne, mapy oraz przewodniki zawierające informacje o drogach wspinaczkowych i trasach turystycznych. Podczas gdy promocja była przede wszystkim zadaniem central związkowych, to uprzystępnianie terenu należało głównie do sekcji. Były one zdane na współpracę z gminami, instytucjami państwowymi odpowiedzialnymi za gospodarkę leśną, właścicielami ziemskimi i ludnością lokalną. Zadania sekcji obejmowały zakładanie nowych dróg oraz ich znakowanie, tak aby podróżni mo-

sformułował po węgiersku, niemiecku i polsku takież wezwanie do utworzenia towarzystwa karpakkiego obejmującego państwa koronne i komitaty na wzór austriackiego związku alpejskiego, które to wezwanie rozpowszechnił we wszystkich częściach krajów karpackich.

37 Ze względu na życzenie niektórych członków dotyczące przeniesienia siedziby towarzystwa do Budapesztu w 1892 roku doszło do rozbicia na pięć sekcji Węgierskiego Towarzystwa Karpackiego, które uformowały nowy Węgierski Związek Turystyczny (Magyar Turista Egyesület) $\mathrm{z}$ siedzibą w Budapeszcie.

38 Siedmiogrodzki Związek Alpejski został później włączony do założonego w 1880 roku Siedmiogrodzkiego Towarzystwa Karpackiego z sekcją „Kronstadt” jako spadek wcześniejszego Związku Alpejskiego.

39 Należało do nich między innymi Morawsko-Śląskie Towarzystwo Sudeckie (1881), Związek Górski Radegast/Pohorská jednota Radhošt' (1884), Biharskie Towarzystwo Karpackie (1888), Towarzystwo Górskie Mecsek (1891), Towarzystwo Beskidzkie (1893) i Towarzystwo Turystyczne po Drugiej Stronie Dunaju/Dunántuli turistaegyesület (1903) w Sopron.

40 Klipp szacuje liczbę Słowaków wśród członków na 10-15\% — idem, Die Hohe Tatra und der Karpathenverein, Karlsruhe 2006, s. 177-178.

${ }^{41}$ Zob. np. list Egide Berzeviczy, prezydenta Węgierskiego Związku Karpackiego, w którym dziękuje za członkostwo honorowe w Towarzystwie Tarzańskim — Ważniejsze pisma wystosowane do Towarzystwa Tatrzańskiego, „Pamiętnik Towarzystwa Tatrzańskiego” 1, 1876, s. 36-44, tu: s. 36. 
gli odnaleźć się w górach ${ }^{42}$. Kształciły one również mężczyzn wywodzących się z lokalnej ludności na przewodników oraz tworzyły ratownictwo górskie. W ten sposób sprofesjonalizowały usługi, w których pośredniczeniem zajmowali się wcześniej miejscowi leśniczy, duchowni oraz notariusze $e^{43}$.

Do udostępniania terenu należała też budowa schronisk, w których podróżni mogli znaleźć nocleg w czasie dłuższych wycieczek. Budowę schronisk poprzedzały długie przygotowania oraz prace sondażowe, a czasami i gorące debaty, które miejsce najlepiej nadaje się pod budowę schroniska ${ }^{44}$. Budowa i wyposażenie schronisk, ale i kosztowny transport materiału były finansowane po części ze składek członkowskich, najczęściej jednak ze sprzedaży udziałów, z prywatnych datków tudzież poprzez sponsoring i kredyty udzielane przez lokalne kasy oszczędnościowe i instytucje kredytowe. Grunt, a po części i potrzebne do budowy drewno były udostępniane przez właściciela gruntu lub instytucje państwowe, przede wszystkim ministerstwo leśnictwa i rolnictwa, często nieodpłatnie ${ }^{45}$. W zamian za to towarzystwa górskie oddawały swoje schroniska również do dyspozycji robotników leśnych. Podobne porozumienia dotyczące wspólnego użytkowania infrastruktury zawierano także z inspekcją celną. Sekcja Hermannstadt Siedmiogrodzkiego Towarzystwa Karpackiego złożyła w 1885 roku wniosek o współużytkowanie strażnicy, a uzyskawszy zgodę inspekcji celnej, zrezygnowała z budowy własnego schroniska ${ }^{46}$.

$\mathrm{Z}$ biegiem dziesięcioleci udostępniano dzięki schroniskom coraz większe części gór do wędrówek i wspinaczek. Węgierskie Towarzystwo Karpackie tylko w pierwszych dziesięciu latach swojej działalności wybudowało 10 schronisk, Siedmiogrodzkie Towarzystwo Karpackie w sumie 38 do I wojny światowej, a Towarzystwo Tatrzańskie w tym samym czasie 11 schronisk oraz 7 altan ${ }^{47}$. Jako członek towarzystwa górskiego miało się prawo do zniżek na noclegi w schroniskach własnego towarzystwa, a także w schroniskach innych związków górskich, z którymi zostały zawarte odpowiednie umowy. Klucz podróżni otrzymywali zazwyczaj w gospodzie lub u mieszkańców położonej niedaleko miejscowości.

42 Prócz statutów towarzystw górskich streszczenie można znaleźć w: F. Dénes, Wegweiser durch die Ungarischen Karpaten, Leutschau 1888.

43 Jahresberichte der Sektionen unseres Vereines. Sektion Broos, „Jahrbuch des Siebenbürgischen Karpathen-Vereins" 4, 1884, s. 146-151, tu: s. 150.

${ }^{44}$ E. Lüdecke, op. cit., s. 96.

45 Na przykład przez hrabiego Telekiego, który przy budowie schroniska nad jeziorem Bulea oddał do dyspozycji sekcji Hermannstadt Siedmiogrodzkiego Towarzystwa Karpackiego swój grunt, drewno, a także swojego leśniczego. Zob. ibidem.

46 Jahresberichte der Sektionen unseres Vereins. Sektion Hermannstadt, „Jahrbuch des Siebenbürgischen Karpathen-Vereins" 6, 1886, s. 199-207, tu: s. 204.

${ }^{47}$ H. Heltmann, Zur Geschichte des Siebenbürgischen Karpatenvereins, [w:] Der Siebenbürgische Karpatenverein 1880-1945. Gedenkband, red. H. Heltmann, H. Roth, Thaur bei Innsbruck 1990, s. 11-26, tu: s. 13; Schroniska i altany Tow. Tatrz. w Tatrach, „Pamiętnik Towarzystwa Tatrzańskiego" 35, 1914, s. LXVI-LXVII. 
Jeśli go nie było, mogło się zdarzyć, że podróżni starali się dostać do schroniska przez włamanie ${ }^{48}$.

Czasopisma związkowe świadczą o tym, że ich członkowie byli w pełni świadomi wielojęzyczności regionu oraz oddziaływania narodowego nazewnictwa ich budowli. Pokazuje to szczególnie dobitnie uroczystość otwarcia Śląskiego Domu nad Wielickim Stawem (Felkersee, Velické pleso), który został zbudowany w 1895 roku przez śląską sekcję Węgierskiego Towarzystwa Karpackiego (zob. ilustracja 3). W czasie uroczystości biorący w niej udział członkowie podkreślali istnienie narodowych linii podziału, jednocześnie wynosząc się ponad nie. Dowcipy o zdobyciu terenu górskiego przez Prusy mieszały się z piosenką:

Kto znalazł tutaj dach nad głową,

Niech poda braterską dłoń

Obcemu chętnie!

Co w dole dzieli narody,

Tego nie zna tu już żadne serce,

Każdy innego tu

Wita jak przyjaciela ${ }^{49}$.

Podkreślanie lub odrzucanie przynależności narodowych w Śląskim Domu wskazuje na to, że wzniesione dla celów turystycznych schroniska włączały się w kompleksową strukturę społeczną. Uwidacznia ją relacja z podróży z 1897 roku autorstwa Karla Kollbacha, alpinisty z Rzeszy Niemieckiej, dotycząca jego wędrówek po Tatrach Wysokich. Będąc w drodze wraz ze swym przewodnikiem wywodzącym się z regionu, napotkał w opuszczonym krajobrazie górskim rodzinę z trzodą bydła, która to rodzina zamieszkiwała prostą chatę; także schronisko Towarzystwa Tatrzańskiego w Dolinie Roztoki zamieszkiwała latem trójka młodych ludzi, a stacjonujący nieopodal pogranicznik często dotrzymywał im towarzystwa. W schronisku nad Morskim Okiem Kollbach trafił w końcu na innych podróżnych. Z polskim profesorem spędzającym tam całe lato, austriackim żołnierzem i polskim gimnazjalistą poczuł się tak bardzo związany, że wysnuł wniosek, iż „przynajmniej w tym cichym zakątku górskim przeciwieństwa między niemieckością a polskością nie istnieją"50. Jak dużą rolę jako element łączący odgrywało podobne pochodzenie społeczne podróżnych wobec różnic narodowościowych, ukazuje w tej samej relacji już kilka dni później, kiedy podnosi dużą różnicę dzielącą ludność niemiecką i polską zamieszkującą wsie górnośląskie. Także góralskie chaty sprawiały na nim wrażenie domów ,zacofanego ludu”, a wsie na drodze

48 Zob. H. Magnesius, Ein Ausflug auf Schneeschuhen in das Zibinsgebirge, „Jahrbuch des Siebenbürgischen Karpathen-Vereins" 17, 1897, s. 72-78, tu: s. 75.

49 J. Müller, Schlesierhaus am Felker-See, ,Jahrbuch des Ungarischen Karpathenvereins” 23, 1896, s. 142-154, tu: s. 151-152.

${ }^{50}$ K. Kollbach, Wanderungen durch die deutschen Gebirge. Von der Tatra bis zur Sächsischen Schweiz. Eine Wanderung durch die Karpathen, Beskiden, das Altvater-, Glatzer, Riesen-, Böhmische Mittelgebirge und die Sächsische Schweiz, Köln 1897, s. 71-73, 79-80. 
z Krakowa do Zakopanego przypominały mu niedawno zwiedzaną berlińską wystawę kolonialną ${ }^{51}$.

Wznoszone przez towarzystwa górskie schroniska różniły się od chat prostego ludu. W wydanej przez Niemiecki i Austriacki Klub Alpejski broszurze O budowie schronisk z 1877 roku znajdujemy pewne zalecenia. Takie plany budowy oraz empiryczne wartości z obszaru alpejskiego były przyjmowane przez członków towarzystw karpackich ${ }^{52}$. W broszurze jej autor Johann Stüdl, przedsiębiorca i członek Związku Alpejskiego z Pragi, wyraźnie odgraniczał schronisko od domu turystycznego i hotelu ${ }^{53}$. Wskazywał, że do wzniesienia schroniska nie jest potrzebny architekt, a jego wyposażenie ma być proste — prócz miejsca do spania w zaleceniach Stüdla była mowa o sprzęcie do gotowania i jedzenia, lampie naftowej, apteczce, grach karcianych oraz o księdze schroniskowej wraz z kasą na opłaty do uiszczenia ${ }^{54}$. Wiele z zainicjowanych przez towarzystwa schronisk budowali lokalni rzemieślnicy, przede wszystkim cieśle i murarze ${ }^{55}$. Wyjątki można spotkać przede wszystkim w regionalnych centrach turystycznych, gdzie będący przedsiębiorcami członkowie towarzystw zatrudniali do projektowania schronisk tych samych architektów, którzy już wcześniej projektowali gospody i inne budynki w regionie. Za przykład może służyć architekt Gedeon Majunke ze Spiskiej Soboty/Georgenberg/Spišská Sobota/Szepesszombat, który zaprojektował wiele domów w okolicach kurortu Stary Smokowiec, zanim w 1899 roku podpisał się pod wykonanym na zlecenie Węgierskiego Towarzystwa Karpackiego projektem Schroniska Tery'ego (Téryho chata), nazwanego tak za węgierskim lekarzem Edmundem Viliamem Terym.

W swych wywodach odnoszących się do budowy schronisk Stüdl okazywał się świadom tego, że budowa schroniska nie odbywała się w pustej przestrzeni i że „brakowało jeszcze zrozumienia ze strony zamieszkujących dolinę"56. Podobne uwagi znajdujemy w wielu współczesnych mu relacjach z podróży, z których dowiadujemy się o nieufnych, wystraszonych czy też rozbawionych mieszkańcach gór. Sytuacja schronisk była tu trudna, a ich listy pełne prac mających na celu naprawę lub odbudowę ${ }^{57}$. Roczne sprawozdania sekcji dokumentują ,wandalizm ludności miejscowej”58 i opisują schronisko jako „pożądany obiekt do ataku dla

51 Ibidem, s. 59, 62.

52 Zob. Vereins-Verhandlungen, „Jahrbuch des Siebenbürgischen Karpathen-Vereins” 1, 1881, s. $153-169$, tu: s. 158.

53 J. Stüdl, Ueber Hüttenbau, ,Zeitschrift des Deutschen und Osterreichischen Alpenvereins” [1877], s. 169-191, tu: s. 169-170.

${ }^{54}$ Ibidem, s. 183-186.

55 Ibidem, s. 169.

56 Ibidem, s. 191.

57 Zob. np. Geschichtlicher Überblick über die Schutzhütten des SKV 1881-1943, [w:] Der Siebenbürgische Karpatenverein 1880-1945..., s. 27-29.

58 Sektionsberichte. Sektion „Szittnya “, „Jahrbuch des Ungarischen Karpathen-Vereines” 12, 1885, s. 227-229, tu: s. 227. 
naszych stroniących od postępu pasterzy"59. Schroniska były często plądrowane lub niszczone przez obrywy skalne, burze tudzież działalność ludzką. Uderzenia piorunów, wypadki z powodu lamp czy też pieca powodowały częste pożary ${ }^{60}$. Podejrzenia o podpalenie stawały się powodem niechęci oraz obarczania winą członków towarzystwa, co przebiegało wzdłuż linii konfliktów związanych z przynależnością narodową ${ }^{61}$.

Na tym tle towarzystwa górskie zajmowały się intensywnie kwestią lepszej ochrony swoich schronisk i podejmowały regularnie wycieczki mające na celu sprawdzenie ich stanu. Nierzadko znajdowano schronisko w opłakanym stanie. Okna, meble i inne elementy wyposażenia były ulubionym łupem złodziei, tak więc wyposażenie było po sezonie każdorazowo zwożone w dolinę. Częściej jednak znajdowano w schroniskach ślady po nieproszonych gościach, którzy bezprawnie weszli do budynku, wyłamując okna i drzwi. Liczne relacje świadczą o tym, że okoliczni pasterze wraz ze swymi trzodami korzystali ze schronisk tak samo jak podróżni z gościnności pasterzy i schronienia u nich. Można to było poznać po tym, że tak samo jak w szałasach pasterskich w środku pomieszczenia rozpalano otwarty ogień, a cała podłoga we wnętrzu budynku pokryta była zwierzęcymi odchodami. Wobec związanych z tym kosztów czyszczenia i napraw jeden z podróżnych zastanawiał się, czy nie lepiej byłoby przerzucić się ze schronisk na mobilne namioty ${ }^{62}$.

Aby powstrzymać ludność lokalną przed niszczeniem, złodziejstwem i niewłaściwym używaniem, towarzystwa przedsiębrały różnorodne środki. Jeśli schronisko nie miało gospodarza, który mógłby go strzec, sięgano po lokalne autorytety. Proszono żandarmerię, aby czujne oko zwróciła nie tylko ku granicy, ale i ku schronisku, a lokalnych duchownych proszono, aby pouczali pasterzy o wartości i celu schroniska ${ }^{63}$. Środki te jednak przynosiły mierne efekty. Również poświęcenie budowli przez proboszcza w obecności miejscowej ludności, postawienie krzyża przed schroniskiem czy umieszczenie wewnątrz obrazów świętych nie chroniło schronisk przed zniszczeniami ${ }^{64}$. O wiele skuteczniejsze były za to podarunki bożonarodzeniowe, praktykowane na wzór związków alpejskich, mające na celu zdobycie sympatii ubogiej młodzieży wiejskiej dla interesów towarzystw

59 Jahresberichte der Sektionen unseres Vereines. Sektion „Hermannstadt“, „Jahrbuch des Siebenbürgischen Karpathen-Vereins” 17, 1897, s. 91-101, tu: s. 97.

60 Taki epizod został przedstawiony w Jahresberichte der Sektionen unseres Vereines. Sektion „Kronstadt“, „Jahrbuch des Siebenbürgischen Karpathen-Vereins” 18, 1898, s. 110-116, tu: s. 111.

${ }^{61}$ M. Pelc, Orte der Selbstpositionierung..., s. 237-238; B. Hoenig, Geteilte Berge..., s. 51.

62 G. Poschner, Einige Exkursionspunkte der Sektion Bistritz-Nassod-Rodna des siebenbürgischen Karpathenvereines, „Jahrbuch des Siebenbürgischen Karpathen-Vereins” 7, 1887, s. 117-148, tu: s. 140.

63 Jahresberichte der Sektionen unseres Vereines. Sektion Bistritz-Naszod-Rodna, „Jahrbuch des Siebenbürgischen Karpathen-Vereins” 4, 1884, s. 165-167, tu: s. 166.

64 Jahresberichte der Sektionen unseres Vereines. Sektion „Schielthal“, „Jahrbuch des Siebenbürgischen Karpathen-Vereins” 13, 1893, s. 118-121, tu: s. 120. 
górskich ${ }^{65}$. Dopiero postępująca rozbudowa infrastruktury oraz zwiększająca się liczba podróżujących w przestrzeni górskiej ułatwiła towarzystwom zapobieganie zniszczeniom i niedozwolonym noclegom w ich schroniskach.

\section{Podsumowanie. Idealizacja jako aktywne zawłaszczanie przestrzeni}

Niniejszy artykuł ukazał, jak funkcjonowała budowa schronisk jako pionierski projekt w turystycznym udostępnianiu przestrzeni górskich. Schroniska były częścią starań o stopniowe uczynienie przestrzeni górskiej bardziej komfortową dla podróżnych. Przez zaangażowanie lokalnych fabrykantów i rzemieślników schroniska wpisywały się w ogólną promocję produktów regionalnych ${ }^{66}$. Podróżnym towarzyszyli poza tym lokalni przewodnicy, po części występujący w strojach ludowych i dbający tym samym o konieczny romantyzm gór ${ }^{67}$. Z czasem miejsce prostej infrastruktury schroniskowej zajmowały często większe restauracje lub założenia hotelowe. O ile przy tym ich nie zastępowały, to dochodziło do przekształcenia funkcji schroniska. Takim przykładem jest pierwsze schronisko w Tatrach - Rainerowa Chata w Dolinie Zimnej Wody, która po wybudowaniu hotelu Kozica (Kamzík) w 1884 roku służyła mu jako drewutnia i piwnica winna (zob. ilustracja 4). Będąca częścią Muzeum Tatrzańskiego Parku Narodowego rekonstrukcja zbudowanego w 1863 roku z inicjatywy gospodarza Johanna Georga Rainera schroniska daje wgląd w taternictwo XIX wieku.

Schronisko będące pionierskim elementem infrastruktury turystycznej w widoczny sposób zależało od zawłaszczenia przestrzeni odbieranej jako dzika. Schronisko było umiejscowione w nieuprzystępnionym z punktu widzenia infrastruktury, a tym samym postrzeganym jako niezamieszkany terenie, który stał w opozycji do zespołów budowlanych wsi, a tym bardziej miast. Wiele relacji podkreśla samotność schroniska w krajobrazie górskim, które stoi samo w dalekiej przestrzeni, organicznie włączone w naturalne otoczenie. Schronisko służy jako ramy, tak aby móc z jego drzwi lub okien podziwiać w czasie odpoczynku krajobraz, lub też staje się elementem scenerii górskiej jak na wspomnianej już litografii Kořistki. To osamotnienie schroniska było też częścią oczekiwań należących do postawy turysty, nawet wtedy gdy miało zostać zastąpione hotelem. Ernst Lüdecke, który w 1883 roku należał do komisji SVK mającej zbadać warunki do budowy nowego schroniska nad jeziorem Bulea (Lacul Bâlea), trafnie opisał stan napięcia, który odczuwało wielu członków towarzystw górskich w związku

65 Jahresberichte der Sektionen unseres Vereines. Sektion „Hermannstadt“, „Jahrbuch des Siebenbürgischen Karpathen-Vereins” 17, 1897, s. 91-101, tu: s. 97.

${ }^{66}$ Na przykład w wypadku Śląskiego Domu Węgiesrkiego Towarzystwa Karpackiego przy doborze fabrykantów i rzemieślników, którzy mieli zapewnić umeblowanie i wyposażenie, wyraźnie brano pod uwagę tylko tych ze Spisza. Zob. J. Müller, op. cit., s. 148.

67 A. Klipp, op. cit., s. 129. 
z turystycznym udostępnianiem gór. Choć ich celem było umożliwienie samodzielnych wycieczek poprzez zmianę krajobrazu, jednocześnie się go obawiali:

Czy jest jeszcze ktoś, kto na poważnie życzy sobie, oby postępująca na nizinach kultura nie wypuściła swych szponów nigdy w nasze góry, oby wygodne hotele $\mathrm{z}$ uśmiechającymi się słodko gospodarzami i ufraczonymi kelnerami nie spłoszyła tego naturalnego romantyzmu ${ }^{68}$.

Wypowiedź ta odzwierciedla funkcję schroniska przyjmowaną przez nie w większości relacji z podróży, a której społeczny wymiar podkreślił tenże artykuł. Jest punktem wyjścia i zamknięcia podróży oraz pozwala na ukazanie właściwego przedsięwzięcia, obramowując opis uciążliwości wędrówki i cudowne widoki. Schronisko daje podróżnym możliwość idealizowania gór poprzez aktywne współkształtowanie przestrzeni górskiej. Włączenie schroniska w krajobraz formuje porządek społeczny w regionie i pokazuje, jak centralne miejsce w idealizacji gór odgrywają pożytki płynące z jego funkcji użytkowej.

Z języka niemieckiego przełożyła Monika Witt

${ }^{68}$ E. Lüdecke, op. cit., s. 101. 